\title{
Evaluation of some lactic acid and probiotic bacteria for their potential for biogenic amine production
}

\author{
Rafaat M. Elsanhoty \\ Department of Industrial Biotechnology, Branch of Food and Dairy Biotechnology, Institute of Genetic \\ Engineering and Biotechnology, Sadat city University, Egypt
}

\begin{abstract}
The potential capability for biogenic amine (BA) production should be taken into account in the selection and implementation of starter and protective cultures to reduce hygienic and toxicological risks. Therefore, this work aimed to study the production of BA from lactic acid bacteria (LAB) used in food products and others isolated from breast-fed infants. The analytical protocol involves the use of PCR and TLC techniques to determine the ability of some LAB to form BA. the results indicated that there are some strains that selected have the ability for BA formation. Six strains from the thirty two examined strains gave positive results for putrescine production and the maximum level was $14.65 \mathrm{mg} / \mathrm{kg}$. On the other hand, six strains yielded positive results for histamine production and the maximum level was $31.77 \mathrm{mg} / \mathrm{kg}$ and demonstrated positive indications for the present of histamine decarboxylase gene hdc. Seven strains produced positive results for tyramines production and the maximum level was $2.85 \mathrm{mg} / \mathrm{kg}$ and proved positive for the presence of tyrosine decarboxylase gene $(t d c)$. Finally, eight strains out of thirty two showed positive results for agamantine production and the maximum level was $174.50 \mathrm{mg} / \mathrm{kg}$ and gave positive signs for the existence of dihydrolase (deiminase) gene which is responsible for agmatine formation. Based on this, it could be concluded that the microorganisms used in food and dairy production should be carefully screened for potential BA production. This is due to the possible horizontal transfer as origin of strain to strain variation of the BA production before and during using in food and dairy industry.
\end{abstract}

Key words: Biogenic amines (BA), Lactic acid bacteria, Histamine, Tyramine decarboxylase, Arginine Putrescine.

\section{Introduction}

Biogenic amines (BA) defined as a naturally occurring low molecular weight compounds involved in various biological activities in most living organisms. However, consuming foods containing high concentrations of BA can trigger human health problems leading to palpitations, hypertension, vomiting, headaches and flushing (Ten Brink et al., 1990; Shalaby, 1996; Silla Santos, 1996; LonvaudFunel and Jogeax 1994; Elsanhoty et al., 2009).

Several research groups support the view that BA are formed in wine making mainly by lactic acid bacteria $(\mathrm{LAB})$ due to the decarboxilation of free amino acids (Coton et al., 1998; Moreno-Arribas et al., 2000; Landete et al., 2008; Constantini et al., 2006; Lucas et al., 2008). In the case of fermented foods, some $\mathrm{LAB}$ are able to convert available amino acid precursors into $\mathrm{BA}$ via decarboxylase or deiminase activities during or following the fermentation process. For this reason, amino acid catabolism by LAB can affect both the quality and safety of fermented foods (Silla Santos, 1996; Lonvaud-Funel and Jogeax 1994; Verges et al., 1999).

Food possesses very rich, diverse and complex microbiota that invades invests them with their organoleptic properties and affects it's their quality. This microbiota is initially derived from starter bacteria, the main function of which is to produce lactic acid at an appropriate rate. However, during manufacture and ripening a complex secondary microbiota (non-starter lactic acid bacteria [NSLAB]) develops (Beresford and Williams, 2004).

BA contamination of food takes place during malolactic fermentation (MLF) due to the presence of lactic bacteria strains. The decarboxylases activities of such strains convert amino acids into BA. In addition agmatine (produced by arginine decarboxylation) is delaminated to putrescine. Assessing the potential risk of BA accumulation in food at an early stage of production will assist in better managing the fermentation process in order to reduce the spoilage. The proposed method detects microorganisms that have amino acids decarboxylases and agmatine deiminase. The result cannot indicate the final BA concentrations, but the risk of BA spoilage is linked to the presence of the genes in the bacteria population (Lucas et al., 2008).

Many publications reported that $\mathrm{LAB}$ can produce $\mathrm{BA}$ in many fermented products including meats (Bover-Cid et al., 2001; Suzzi and Gardini, 2003; Ruiz-Capillas and Jimenez- Colmenero, 2004; Aymerich et al., 2006, Arena et al., 2007), many different cheese varieties (Burdychova and Komprda, 2007; Fernández et al., 2007a Fernández et al., 2007b), wine (Coton et al., 1998; Lonvaud-Funel and Jogeax 1994 ; Moreno- 
Arribas et al., 2003; Moreno-Arribas and Polo, 2008; Izquierdo Canas et al., 2009) and cider (Del Campo et al., 2000; Garai et al., 2006, 2007). Decarboxylase activities exhibited by LAB in acidic environments encountered during wine and cider fermentation may play a role in providing an additional mechanism for energy generation as well as acid stress tolerance (Konings, 2002, coton et al., 2010).

The main of BA produced by LAB species are histamine such as histidine decarboxylase (hdc) (Lonvaud-Funel and Joyeux, 1994; Coton et al., 1998), tyramine via tyrosine decarboxylase (tyrdc) (Lucas et al., 2003) and putrescine via ornithine decarboxylase (odc) (Arena and Manca de Nadra, 2001) or agmatine deiminase (agdi) pathway (Lucas et al., 2007). Amongst the prevalent BA, putrescine can also enhance the toxic effects of histamine and tyramine and also react with nitrites to form nitrosamines (Wathersen et al., 1975).

Marcobal et al. (2006) developed methods for detecting tyramine-producing microorganisms. However, these are commonly long and tedious, as they require the isolation of microorganisms, and do not allow the identification of microorganisms without several extra microbiological or enzymatic tests being performed. Fortunately, the increasing number of sequences and genomes deposited in public databases, especially those regarding the tyrosine decarboxylation genes of LAB, has allowed the development of molecular methods to detect their presence (Coton et al., 2004, Landete et al., 2007, coton et al., 2008). These culture-independent methods are specific, sensitive and rapid, and are subject to less variability than phenotypic characterization. Nevertheless, their main drawback is that they are not quantitative, but recently a quantitative a approach devised.

Ladero et al. (2010) described the real Time PCR (qPCR) assay that allows the quantification of tyramine-producing microorganisms in cheese based on the specific amplification of the tdc gene, for the detection, quantification and identification of bacteria with the ability to produce tyramine. This method was found to be specific and showed a wide dynamic range, thus allowing the quantification of these tdc bacterial groups among the complex microbiota of cheese._Until now, few studies have been carried out on cider $\mathrm{LAB}$ and BA production. Amongst LAB species isolated from Spanish ciders, only few $L$. diolivorans strains appeared to be histamine-producers as well as to a lesser extent a $L$. collinoides strain (Garai et al., 2007). In another study, six L. spp. as well as $O$. oeni strains were shown to produce histamine in ciders (Del Campo et al., 2000).

In a survey of 118 wines randomly chosen in different wine-producing areas of Southwest France, Coton et al. (1998) found that the presence of histamine-producing bacteria is not rare. Almost half of the tested wines possessed bacteria carrying the histidine decarboxylase gene wherein all of strains belonged to $O$. oeni. In contrast, formation of histamine was not observed in any species that may be involved in malolactic fermentation (Straub et al., 1995).

Gonza'lez de Llano et al. (1998) described two strains of Leuconostoc from of dairy origin showing tyrosine decarboxylase activity. These results suggest that Leuconostoc may be responsible for tyramine production in wines, in addition to L. brevis strains previously described (Moreno-Arribas et al., 2000). Several BA-forming species are of importance in food fermentations. In cheese, the role of contaminating strains of L. brevis and L. buchneri in the formation of tyramine and histamine has been concretely established. It can be derived from investigations of Straub et al. (1995) that some strains of $L$. buchneri may also contribute to the formation of putrescine and cadaverine.

Garai et al. (2007) showed that one cider strain belonging to the $L$. diolivorans species can produce tyramine. This results suggests that the main BAproducers amongst cider $\mathrm{LAB}$ appear to be histamine-producers and that BA-production levels are low.

Martin-Alvarez et al. (2006) indicated that the choice of starter cultures is fundamental to guarantee the quality of the final product. For this reason, the inability to form BA should be an important criterion in the selection of starter cultures for the production of fermented foods and beverages. Inoculation with starter cultures which are unable to produce $\mathrm{BA}$ is a viable option for the control of these compounds in foods. Before using $\mathrm{LAB}$ in food production, a quantitative analysis of BA is very essential to confirm the bacterial production. Therefore, this work aimed to detect specific lactic bacteria strains that have coding genes for the enzymes involved in BA production isolated from some food products of different geographical origins. Then, these were screened for potential BA-producers using both molecular methods and thin layer chromatography (TLC).

\section{Materials and Methods}

\section{Materials}

\section{Strains and media}

Tables 1 indicate the strains under investigation. The probiotic strains candidate: Lactobacillus acidophilus $\mathrm{P}$ 2, 4, 5, 6, 7, 8, 9, 112, 106; Lactobacillus plantarum p1; Lactobacillus brevis p102; Lactobacillus pentosus p160 and Enterococcus faecium p187 BL bifidobacterium longum were identified by Mahrous (2006). Strains were isolated from healthy, breast-fed infants (15-30 days old) and used after the selection had been done according to Bergey's Manual of Determinative Bacteriology (Holt et al., 1994) with confirm the identification by 
SDS-PAGE technique and API System. The strains were tested for their probiotic characteristic, e.g., gastric acid resistance, bile salt tolerance, antibacterial activity, adhesion to human mucus. Lactobacillus strains were cultivated in MRS (de Man Rogosa Sharpe) broth (Lab M, IDG, UK) and incubated at $37{ }^{\circ} \mathrm{C}$ in $\mathrm{BBL}$ anaerobic jar (Becton Dickinson Microbiology Systems, Sparks, MD) provided with disposable BBL gas generating pack $\left(\mathrm{CO}_{2}\right.$ system envelopes, Oxoid, Ltd., West Heidelberg, Victoria, Canada). All LAB strains under investigation were grown at $30{ }^{\circ} \mathrm{C}$ in MRS broth supplemented with or without $2.5 \mathrm{~g} / \mathrm{l}$ L-tyrosine disodium salt (Sigma-Aldrich, USA), $2.5 \mathrm{~g} / \mathrm{l}$ Lhistidine mono hydrochloride, $2.5 \mathrm{~g} / \mathrm{l}$ L-ornithine monohydrochloride, $2.5 \mathrm{~g} / \mathrm{L}$ L-lysine mono hydrochloride and/or $1 \mathrm{~g} / \mathrm{L}$ agmatine sulfate salt (Sigma, USA). Cultures were incubated without agitation for $24 \mathrm{~h}$ to 8 days according to the species.

\section{Chemicals and reagents}

Amines (histamine, putrescine, cadaverine, and tyramine) as their crystalline hydrochlorides, dansyl chloride (5-dimethylaminonaphtalene-1- sulphonyl) and TLC plates $(20 \times 20 \mathrm{~cm}$ aluminium sheets coated with $0.20 \mathrm{~mm}$ silica gel G-60) were obtained from Merck company. All chemicals used were of analytical grades.

\subsection{Detection of Biogenic amines (BA) producing.}

\subsubsection{DNA extraction from bacterial culture}

DNA was extracted from pure cultures cells of 2 $\mathrm{mL}$ of culture were harvested by centrifugation at $13000 \mathrm{~g}$ for $15 \mathrm{~min}$. The pellet is then suspended in $600 \mu \mathrm{L}$ TE buffer (Tris-HCl $10 \mathrm{mM}$, EDTA $1 \mathrm{mM}$ ) containing lysozyme $(10 \mathrm{mg} / \mathrm{mL})$ and incubated at 37 ${ }^{\circ} \mathrm{C}$ for $30 \mathrm{~min}$. The extraction was continued according to the methods described by De et al. (2010). The final pellet obtained was dissolved in $50 \mu \mathrm{l}$ Tris-EDTA (10:1, pH 8.00) and stored frozen at $-20{ }^{\circ} \mathrm{C}$ till further analysis.

\subsubsection{Quantification of genomic DNA}

Genomic DNA concentration was determined by recording the absorbance at $260 \mathrm{~nm}\left(\mathrm{~A}_{260}\right)$ using a Nanodrop spectrophotometer (Wilninggto, DE, USA, and spectrophotometer 2000 according to the Manufacturer's producer's instructions). The purity of the DNA was determined from the $\mathrm{A}_{260} / \mathrm{A}_{280}$ ratio to investigate the DNA quantity (Sambrock, et al. 1989). DNA purity was measured using the appropriate ratio of OD260:OD280 (1.65-1.85). Concentrations (ng/lL) and A260/ A280 readings were recorded for each sample. The quality of the isolated DNA was also evaluated by ( $0.9 \%$ agarose) gel electrophoresis using $2 \mu \mathrm{l}$ of isolated DNA. The type of band pattern indicates the quality of the isolated DNA. A known amount of bacteriophage lambda DNA was used to compare the intensity and approximate size of the isolated DNA. The extracted
DNA concentration was measured and adjusted by dilution to $20-25 \mathrm{ng} / \mathrm{lL}$ prior to PCR using bidistilled, deionised and sterilized water (Fluka, Germany).

\subsubsection{Oligonucleotide primers}

The primers used in this study together with their target specific part of the investigated DNA are listed in Table 2). All primers were synthesized by Biosynthesis (Inc., USA), and obtained in a lyophilized state. All primers were solved before use to obtain a final concentration of $20 \mathrm{pmol} / \mathrm{l}$ for each.

\subsubsection{DNA amplification and PCR condition}

PCR was carried out on thermo cycler (Biometra, T1) using a prepared master mix. Amplification by PCR is performed in $25 \mu \mathrm{l}$ reaction mixture containing $12.5 \mathrm{ng}$ of template DNA, $20 \mathrm{mM}$ Tris$\mathrm{HCl}, \mathrm{pH} 8.0,50 \mathrm{mM} \mathrm{KCl}, 2.5 \mathrm{mM} \mathrm{MgCl} 2,200 \mu \mathrm{M}$ of each dNTP, $1 \mathrm{mM}$ of each primer, and $1 \mathrm{U}$ of DNA polymerase and water was added to reach $25 \mu \mathrm{l}$. Oligonucleotide primer sequences for the amplification of internal fragments of the genes coding histidine-, tyrosine, ornithine decarboxylase, and agmatine deiminase by PCR have been designed by a number of research groups (Coton and Coton. 2005, Laucas et al. 2007 and Laucas et al. 2008). The PCR reactions were performed according to the cycling parameters given in table 3 (PCR conditions). The PCR products are analyzed by electrophoresis in $1.5 \%$ agarose gel and revealed under UV after being stained with ethidium bromide.

\subsection{Detection of specific BA-producing strains 2.3.1. Detection of histamine-producing strains}

The methods described by Coton and Coton (2005), with the specific primers HDC3/HDC4 were used to detect the capacity of the strains to produce histamine. The hdcA gene was amplified as codes to detect the enzyme histidine decarboxylase.

\subsubsection{Detection of tyramine-producing strains}

To detect the tyrosine decarboxylase gene in the strains under investigation, tdc gene was used according to the method described in Marcobal et al, 2005.

\subsubsection{Detection of putrescine-producing strains} (via ornithine decarboxylase).

The gene $(o d c)$ used as code for the conversion of ornithine to putrescine was detected in the strains under investigation according to the method described in Marcobal et al. (2004).

\subsubsection{Detection of agmatine dihydrolase (Deiminase) gene in the strains}

The primer pair AGD1f/AGDIR were used for detection of agmatine dihydrolase (Deiminase) gene according to the methods described by Laucas et al. (2007). 
Table 1. Origin and incubation conditions of various bacterial strains used for investigate

\begin{tabular}{|c|c|c|}
\hline Strains & Origin & Growth temperature $(C)$ and $\mathrm{O}_{2}$ need \\
\hline Lactobacillus acidophilus ATCC 20552 & 1 & $37^{\circ} \mathrm{C}$ Anaerobic \\
\hline Lactobacillus paracasei TISTR 453 & 2 & $30^{\circ} \mathrm{C}$ Aerobic \\
\hline Lactobacillus rhamnosus TISTR 541 & 2 & $37^{\circ} \mathrm{C}$ Aerobic \\
\hline Lactobacillus salivarius TISTR 390 & 2 & $37^{\circ} \mathrm{C}$ Aerobic \\
\hline Lactobacillus acidophilus TISTR 450 & 2 & $37^{\circ} \mathrm{C}$ Anaerobic \\
\hline Lactobacillus johnsonii ATCC 33200 & 3 & $30^{\circ} \mathrm{C}$ Aerobic \\
\hline Lactobacillus casei DSMZ 20011 & 4 & $30^{\circ} \mathrm{C}$ Aerobic \\
\hline Lactobacillus acidophilus DSM 9126 & 4 & $37^{\circ} \mathrm{C}$ Aerobic \\
\hline Lactobacillus acidophilus DSM20079 & 4 & $37^{\circ} \mathrm{C}$ Aerobic \\
\hline Lactobacillus acidophilus DSM20242 & 4 & $37^{\circ} \mathrm{C}$ Aerobic \\
\hline Lactobacillus sanfrasiscensis DSM20451 & 4 & $37^{\circ} \mathrm{C}$ Aerobic \\
\hline Lactobacillus plantrum & 3 & $30^{\circ} \mathrm{C}$ Aerobic \\
\hline Bifidobacterium infantis DSMZ 20088 & 4 & $37^{\circ} \mathrm{C}$ Anaerobic \\
\hline Bifidobacterium angulatum DSMZ 20098 & 4 & $37^{\circ} \mathrm{C}$ Anaerobic \\
\hline Lb. delbrueckii subsp bulgaricus & 3 & $37^{\circ} \mathrm{C}$ Aerobic \\
\hline Lactobacillus acidophilus $P 2$ & 5 & $37^{\circ} \mathrm{C}$ Anaerobic \\
\hline Lactobacillus acidophilus P4 & 5 & $37^{\circ} \mathrm{C}$ Anaerobic \\
\hline Lactobacillus acidophilus P5 & 5 & $37^{\circ} \mathrm{C}$ Anaerobic \\
\hline Lactobacillus acidophilus P 6 & 5 & $37^{\circ} \mathrm{C}$ Anaerobic \\
\hline Lactobacillus acidophilus P7 & 5 & $37^{\circ} \mathrm{C}$ Anaerobic \\
\hline Lactobacillus acidophilus $P 8$ & 5 & $37^{\circ} \mathrm{C}$ Anaerobic \\
\hline Lactobacillus acidophilus $P 9$ & 5 & $37^{\circ} \mathrm{C}$ Anaerobic \\
\hline Lactobacillus acidophilus P112 & 5 & $37^{\circ} \mathrm{C}$ Anaerobic \\
\hline Lactobacillus acidophilus P106 & 5 & $37^{\circ} \mathrm{C}$ aerobic \\
\hline Lactobacillus plantarum pl & 5 & $37^{\circ} \mathrm{C}$ aerobic \\
\hline Lactobacillus brevis p102 & 5 & $30^{\circ} \mathrm{C}$ aerobic \\
\hline Lactobacillus pentosus p160 & 5 & $30^{\circ} \mathrm{C}$ aerobic \\
\hline Enterococcus faecium p187 & 5 & $42^{\circ} \mathrm{C}$ aerobic \\
\hline Bifidobacterium longuium & 5 & $37^{\circ} \mathrm{C}$ Anaerobic \\
\hline Lactobacillus brevis & 5 & $30.0^{\circ} \mathrm{C}$ aerobic \\
\hline Lactobacillus buchneri & 5 & $37^{\circ} \mathrm{C}$ aerobic \\
\hline Streptococcus thermophilus & 5 & $37^{\circ} \mathrm{C}$ aerobic \\
\hline
\end{tabular}

(1) Cairo (MIRCEN), Faculty of Agriculture, Ain Shams University

(2) Thailand Institute of Scientific and Technological Research, Bangkok, Thailand.

(3) American Type Culture Collection, Manassas, VA.

(4) Deutsche Sammlung von Mikroorganismen und Zellkulturen Gmbh (DSMZ, Germany).

(5) Personal Communication with Associate Prof. Dr. Hoda Mahrous Abbas, Sadat City University, Institute of Genetic engineeing and biotechnology, Industrial Biotechnology Department, Food and Dairy Biotechnology Branch. 
Table 2. Oligonucleotide primer pairs sequence and their target elements.

\begin{tabular}{|c|c|c|c|c|}
\hline Primer & Sequence & $\begin{array}{l}\text { Fragment } \\
\text { length }\end{array}$ & Target element & References \\
\hline hdcAf/ hdcAr & $\begin{array}{l}\text { 5'-ATGAAGCCAGGACAAGTTGG 3' } \\
\text { 5'-AATTGAGCCACCTGGAATTG 3' }\end{array}$ & 84 bp & Histidine decarboxylase gene & Coton and Coton (2005) \\
\hline Tdcf/ tdcr & $\begin{array}{l}\text { 5'-CAAATGGAAGAAGAAGTTGG 3' } \\
\text { 5'-GAACCATCAGCA ACAATGTG 3' }\end{array}$ & 213 bp & $\begin{array}{c}t d c \text { gene } \\
\text { Tyrosine decarboxylase gene }\end{array}$ & Laucas et al. (2008). \\
\hline HDC3 /HDC4 & $\begin{array}{c}\text { 5'-GATGGTATTGTTTCKTATGA 3' } \\
\text { 5'-CCAAACACCAGCATCTTC 3' }\end{array}$ & $435 \mathrm{bp}$ & Histidine decarboxylase gene hdc & Coton and Coton (2005) \\
\hline Odcf/ Odcf & $\begin{array}{l}\text { 5'-TGCA CTTCCATATCCTCCAG-3' } \\
\text { 5'-GAATTTCTGGAGCAAATC CA-3' }\end{array}$ & $127 \mathrm{bp}$ & Ornithine decarboxylase gene & $\begin{array}{l}\text { Granchi et al. ( 2006) } \\
\text { Nannelli et al. (2008) }\end{array}$ \\
\hline AGD1f/AGDIR & $\begin{array}{l}\text { 5'-GAACGACTAGCAGCTAGTTAT-3' } \\
\text { 5'-CCAATAGCCGATACTACCTTG-3' }\end{array}$ & $90 \mathrm{bp}$ & Agmatine Dihydrolase (Deiminase) gene & Laucas et al. (2007) \\
\hline ODF/ODR & $\begin{array}{l}\text { 5' CATCAAGGTGGACAATATTTCCG 3' } \\
\text { 5' CCGTTCAACAACTTGTTTGGCA 3' }\end{array}$ & $500 \mathrm{bp}$ & detection of putrescine gene & Granchi et al. (2006) \\
\hline
\end{tabular}

Table 3.Time/temperature profiles for qualitative PCR with DNA extracted from microorganisms using the primer pairs described in Table 2

\begin{tabular}{|c|c|c|c|c|c|c|}
\hline Primer pair & Initial denaturation & Denaturation & Annealing & Extension & Cycles & Reference \\
\hline HDC3 / HDC4 & $95^{\circ} \mathrm{C}, 30 \mathrm{~s}$ & $95^{\circ} \mathrm{C}, 30 \mathrm{~s}$ & $48^{\circ} \mathrm{C}, 45 \mathrm{~s}$ & $72^{\circ} \mathrm{C}, 2 \mathrm{~min}$ & 35 & Coton and Coton (2005) \\
\hline hdcAf/hdcAr & $95^{\circ} \mathrm{C}, 5 \mathrm{~min}$ & $95^{\circ} \mathrm{C}, 30 \mathrm{~s}$ & $55^{\circ} \mathrm{C}, 30 \mathrm{~s}$, & $72^{\circ} \mathrm{C}, 30 \mathrm{~s}$ & 40 & Coton and Coton (2005) \\
\hline Tdcf/tdcr & $95^{\circ} \mathrm{C}, 30 \mathrm{~s}$ & $95^{\circ} \mathrm{C}, 30 \mathrm{~s}$ & $52^{\circ} \mathrm{C}, 30 \mathrm{~s}$ & $72^{\circ} \mathrm{C}, 2 \mathrm{~min}$ & 30 & Marcobal et al. (2005) \\
\hline P1rev/p0303 & $95^{\circ} \mathrm{C}, 1 \mathrm{~min}$ & $95^{\circ} \mathrm{C}, 30 \mathrm{~s}$ & $50^{\circ} \mathrm{C}, 1 \mathrm{~min}$ & $72^{\circ} \mathrm{C}, 1 \mathrm{~min}$ & 35 & Landete et al. (2007) \\
\hline Agdif/agdif & $95^{\circ} \mathrm{C}, 5 \mathrm{~min}$ & $95^{\circ} \mathrm{C}, 30 \mathrm{~s}$ & $55^{\circ} \mathrm{C}, 30 \mathrm{~s}$ & $72^{\circ} \mathrm{C}, 2 \mathrm{~min}$ & 35 & Lucas et al. (2007) \\
\hline ODCF/OCDR & $95^{\circ} \mathrm{C}, 5 \mathrm{~min}$ & $95^{\circ} \mathrm{C}, 30 \mathrm{~s}$ & $55^{\circ} \mathrm{C}, 30 \mathrm{~s}$ & $72^{\circ} \mathrm{C}, 30 \mathrm{~s}$ & 40 & $\begin{array}{l}\text { Granchi et al. (2006) } \\
\text { Nannelli et al. (2008) }\end{array}$ \\
\hline
\end{tabular}




\subsection{BA extraction and determination}

\subsubsection{BA extraction}

To extract and determine histamine, putrescine, cadaverine, spermidine, spermine and tyramine in all homogenised tested samples, the method described by Mietz and Karmas (1978) and Maijala and Eerola (1993) was applied. Briefly, samples $(100 \mathrm{~mL})$ of microbial culture) were centrifuged and supernatants were blended with $125 \mathrm{ml}$ of trichloroacetic acid (TCA, 5\%) for 3 min using a Warning blender. The homogenised sample was filtered using Watman No. (1). The filtrate $(10 \mathrm{~mL})$ was transferred into a glass tube with $4 \mathrm{~g} \mathrm{NaCl}$ and 1 $\mathrm{mL}$ of $\mathrm{NaOH}(50 \%)$, then shacked and extracted with $(3 \times 5.0 \mathrm{ml})$ n-butanol: chloroform $(1: 1 \mathrm{v} / \mathrm{v})$, the upper layers were transferred to separating funnel $(100 \mathrm{ml})$ with $15 \mathrm{ml} \mathrm{n}$-heptane and extracted with (3 $\mathrm{x} 1.0 \mathrm{ml}) \mathrm{HCl}(0.2 \mathrm{~N})$. The $\mathrm{HCl}$ layers were collected in a glass tube and evaporated to dryness at $95^{\circ} \mathrm{C}$ aided by a gentle current of air, submitted to dansylchloride derivatization $\left(1 \mathrm{~h}\right.$ at $\left.55^{\circ} \mathrm{C}\right)$ for formation of dansylamines. Saturated $\mathrm{NaHCO}_{3}$ solution $(0.5 \mathrm{ml})$ was added to the residue of both samples and working standards and carefully mixed, then $1.0 \mathrm{ml}$ dansyl chloride solution was added and thoroughly mixed using vortex mixer. The mixture was incubated at $55{ }^{\circ} \mathrm{C}$ for $45 \mathrm{~min}$. Distilled water $(10 \mathrm{ml})$ was added to the dansylated mixture and vigilantly mixed. The mixture was extracted with (3 x $5.0 \mathrm{ml}$ ) diethyl ether. The ether layers were carefully evaporated at $35{ }^{\circ} \mathrm{C}$ in a dry bath with aid of current air. The dry film was kept under $-20^{\circ} \mathrm{C}$ for TLC analysis of BA.

\subsubsection{Determination of dansylamines by TLC densitometer}

One-dimensional silica gel G 60 TLC plates $(20 \mathrm{x}$ $20 \mathrm{~cm}$ ) (Merck, Darmstadt, Germany) were used for the chromatographic separation of the studied dansylamines. The dry film of standards and samples were dissolved in $500 \mu \mathrm{l}$ methanol. The dissolved standards and samples $(10 \mu \mathrm{l})$ were spotted. The plate was developed using chloroform: benzene: triethyl amine (6: 4.5:1 v/v/v). The plate was dried at room temperature and visualized using UV lamp $(365 \mathrm{~nm})$. The resulting spots were then marked and the marked areas were determined in Microanalysis Centre, Faculty of science, Cairo University using CS- 9000 Dual wavelength flying spot scanning densitometer (SHIMADZU) at wavelength $254 \mathrm{~nm}$. Standard curve of each dansylamine was used to calculate the concentrations of BA in the tested samples.

\section{Results and Discussion}

\subsection{DNA isolation}

The detection of genes that gave microorganisms the ability for BA production involved three steps. The first step involves genomic DNA extraction and amplification of specific microorganisms sequence (16s $\mathrm{r}$ DNA) from microorganisms DNA. This procedure is necessary to discriminate between negative and positive results due to inhibited amplification (Gezginc et al., 2013). The second step entails amplification of specific sequences, represented by each histidine decarboxylase gene, tyrosine decarboxylase gene, ornithine decarboxylase gene, agmatine dihydrolase (Deiminase) gene and detection of putrescine gene. The quality of the extracted DNA from the strains using CTAB method was examined by electrophoresis through a $0.8 \%$ agarose gel (Fluka). DNA bands of high intensity appeared in the lanes (Figs. 1 A), showing high yield of genomic DNA. The results presented in this study confirmed that the $\mathrm{CTAB}$ protocol can be used for DNA extraction and purification from the strains as an initial step of detection of different decarboxylase genes. After agarose gel electrophoresis, the DNA was present as a high molecular weight band from all of the strains (Figs. 1 B).

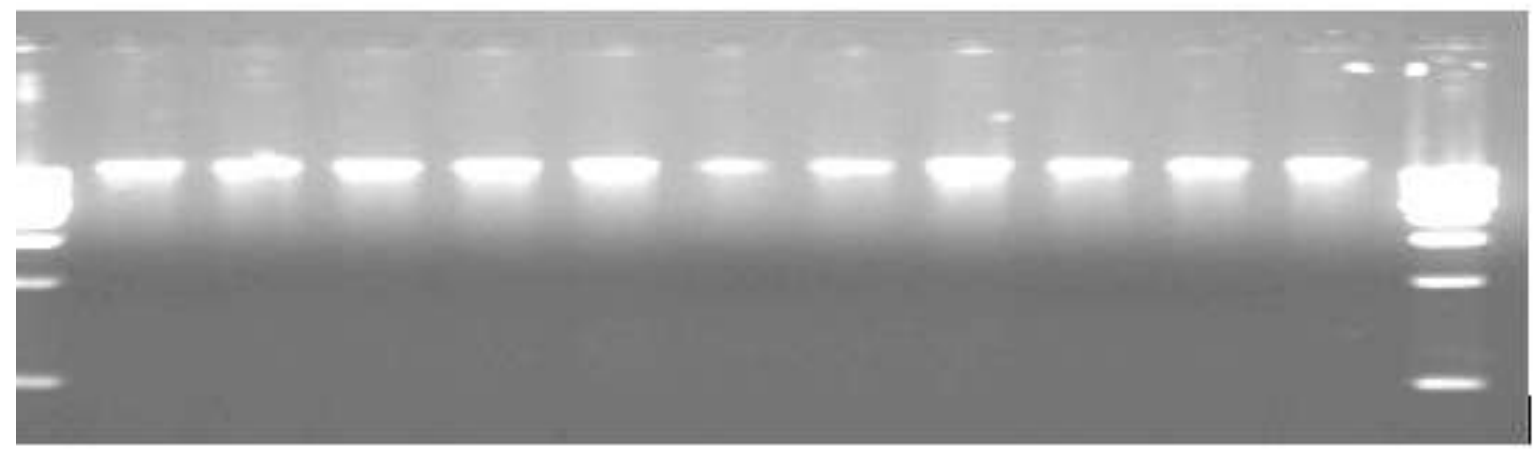

Fig. 1A. Example of DNA electrophoresis on 0.5 agarose gel of DNA extracted from the strains 


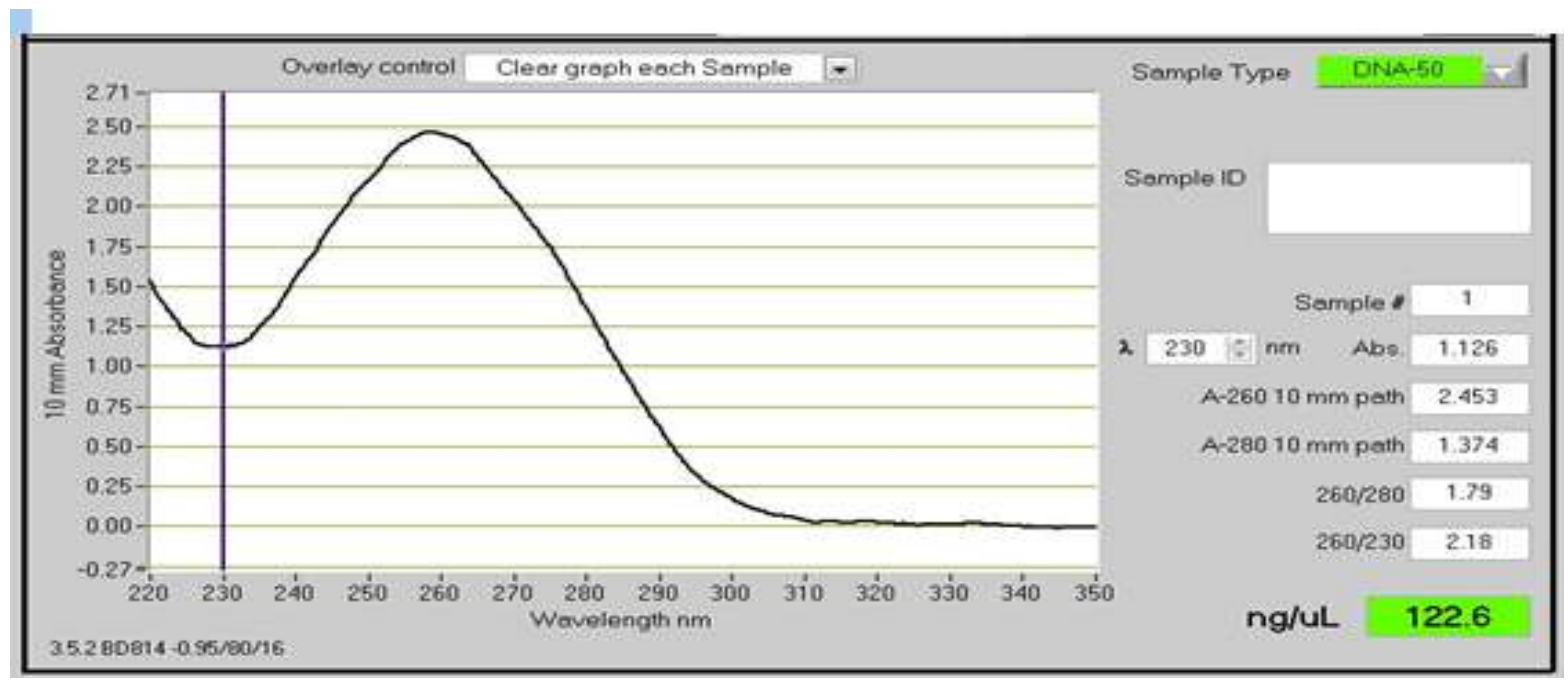

Fig.1.B. Examples of the results obtained by NANODROP 2000 spectrophotometer for DNA amount of extracted DNA from some strains using CTAB method.

\subsection{Detection of BA genes}

\subsubsection{Detection of histidine, tyrosine decarboxylase hdc and $t d c$ genes}

Sensitive detection of BA-producing bacteria in the first stages is important for preventing BA production and accumulation in food. The application of conventional culture technique for detecting BA-producing bacteria is often tedious and unreliable. On the other hand, it is more important to find a good correlation between histamine production and the presence of hdcA gene. To detect the histidine decarboxylase gene, hdc in the strains under investigation, the primer pair HDC3 /HDC4 was used and the positive samples gave PCR products at 435 bp (Coton and Coton 2005). Figure 2 A presented the positive results obtained using the primer pair HDC3 /HDC4 lines 2, 3, 4, 5, 6, 7. To confirm these results the primer pair hdcAf/ hdcAr was used as it is more sensitive and the PCR reveal at 123 bp (Coton and cotton, 2005) as shown in Figure 2.B. Based on the outcomes exhibited in figure 2.B, it can be concluded that only six strains (S. thermophilus, L. lactis, L. brevis, L. pentosus p160, Enterococcus faeciumand and L., rhamnosus TISTR 541) from the strains under investigation have given positive results for the presence of histidine decarboxylase gene hdc. Data in Figure 3 indicate the positive results acquired by the primer pair Tdcf/ tdcr by PCR to detect the tyrosine decarboxylase gene tyc. The PCR amplicon appears at $213 \mathrm{bp}$. Notably, the same strains that gave positive results for the existence of histidine decarboxylase hdc, have also demonstrated positive results for the presence of tyrosine decarboxylase gene tdc. These findings are in agreement with the results of Gezginc et al.
(2013) who showed that $S$. thermophilus isolates have the ability to form BA, especially histamine, and tyramine. A similar evidence is provided by Lorencová et al. (2012) who found that some probiotic strains (Bifidobacterium and L. rhamnosus) are detected for BA production. The orientation of these genes polycistronic hdc cluster (hdcAPB) was identified in $S$. thermophilus. The cluster began with the hdcA gene, followed by a transporter hdcP gene and ended with hdcB gene, which catalyses the maturation of the pyruvoyl-dependent hdcA (CallesEnriquez et al. 2010). The gene order of hdcAPB oper and is similar to $S$. capitis and $C$. perfringens, which, however, lack hdcB (De las Rivas et al., 2008). $\mathrm{HdcB}$ is a functional enzyme and substoichiometric amounts of hdcB were required to cleave hdcA (Trip et al., 2011). The hdc cluster is located either on the plasmid or on the chromosome. In L. hilgardii and T. halophilus strains hdc cluster is located on the plasmid (Satomi et al., 2008), whereas in $S$. thermophilus strain the cluster is located on the chromosome (Calles-Enriquez et al., 2010). The sequence of the hdc cluster has homology with a phase resistance pER35 plasmid from $S$. thermophilus. In addition, tyrosine decarboxylase gene (tdcA) was identified in S. thermophilus strains and L. brevis (La Gioia et al., 2011, coton and coton 2009). These similarities point to a horizontal transfer of hdc cluster and tdcA in S. thermophilus. Moreover, the strains that gave positive results were similar with gene sequence have showed similarity with tdc $\mathrm{A}$ and hdc genes. The hdcA enzyme was synthesized in milk even in the absence of histidine. Rossi et al. (2011) stated that the enzyme activity in cell-free extract obtained from cultures grown with or without histamine was not significantly different. 


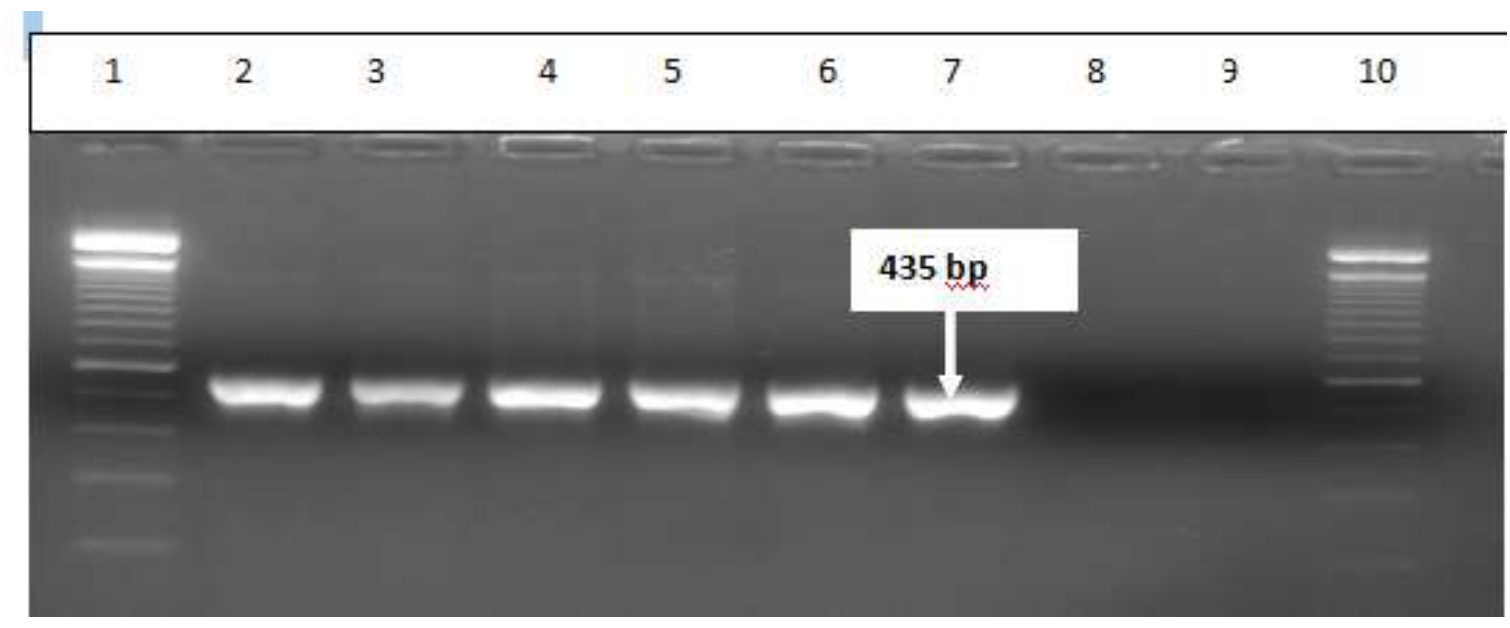

Figure 2A. Presented the positive results that obtained by using the primer pair HDC3 /HDC4, in the strains $S$. thermophilus, L. lactis, L. brevis, Lactobacillus pentosus p160, Enterococcus faecium and L. rhamnosus TISTR 541 respectively lines $2,3,4,5,6$ and 7 .

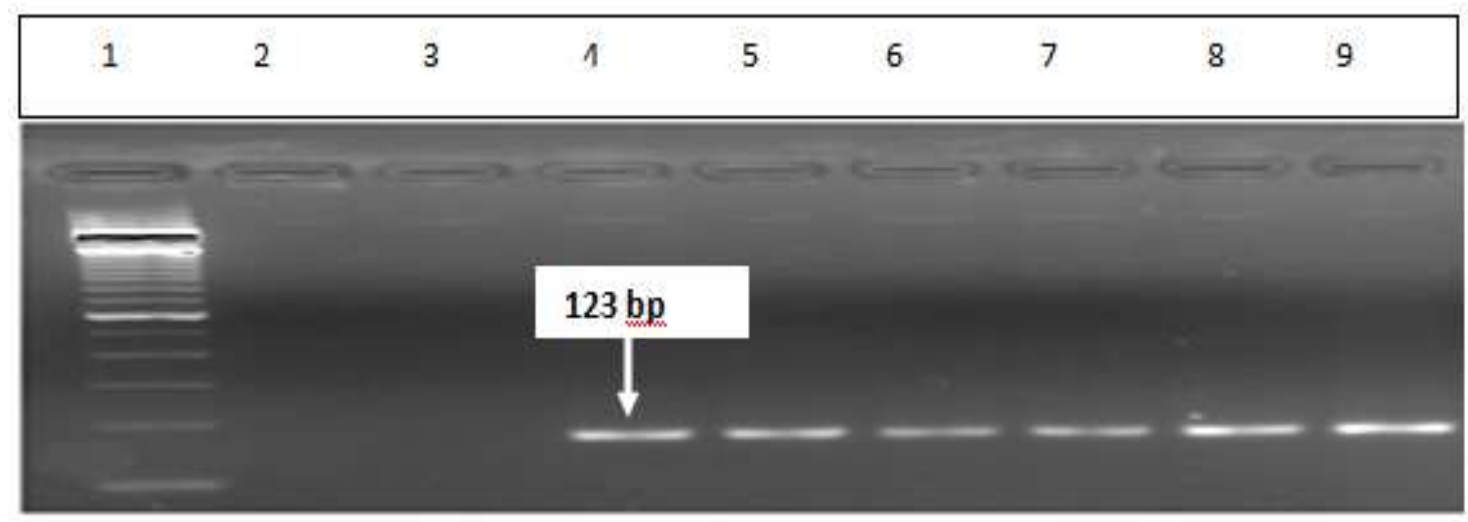

Figure 2B. Presented the positive results that obtained by using the primer pair hdcAf/ hdcAr, $S$.

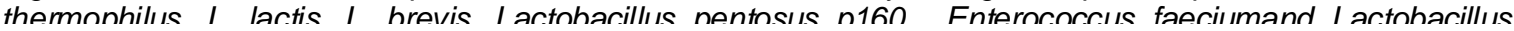

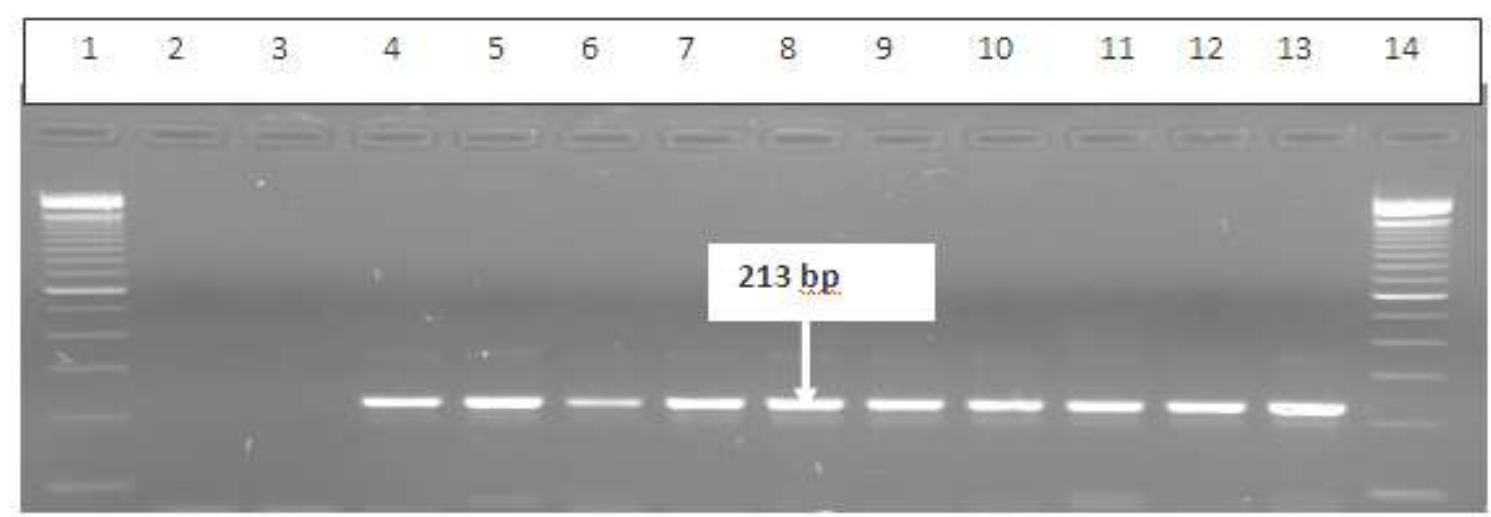

Figure 3. Presented the positive results that obtained by using the primer pair hdcAf/hdcAr for identification of Tyrosine decarboxylase gene lanes 1 and 14: DNA ladder $100 \mathrm{bp}$, Lane 2 and 3 PCR control negative, lanes 4 and 5: PCR products by DNA from S. thermophilus, lanes 6 and 7, PCR products by DNA from L. brevis $p 102$ and $L$. brevis, lanes 8 and 9:PCR products by DNA from Lactobacillus pentosus $p 160$ and Enterococcus faecium, lanes 10 and 11 PCR products by DNA from L. rhamnosus TISTR 541 and $L$. casei DSMZ 20011, lanes 11 and 12: PCR products by DNA from L. paracasei TISTR 453 and Lb. delbrueckii subsp. bulgaricus respectively. 
3.2.2. Detection of Ornithine, Decarboxylase, Agmatine Dihydrolase genes.

The primer Odcf/ Odcr was used to detect the Ornithine decarboxylase gene and PCR products were appeared at $127 \mathrm{bp}$ (Granchi et al., 2006), whereas, the primer AGD1f/AGDIR was used to detect the agmatine dihydrolase gene. The PCR products were revealed at $90 \mathrm{bp}$ (Laucas et al., 2007). Data in Figure $4 \mathrm{~A}$ (lanes 4 and 5) $L$. Paracasei TISTR 453, lanes 6 and 7 for L. casei DSMZ 20011, lanes 8 and 9 L. brevis, lanes 10 and $11 S$. thermophilus presented the positive results obtained from tested stains. While the remaining strains did not given any positive results. The results reported herein show that only 4 strains have the gene for Ornithine decarboxylase. Similar results were observed by Landete et al. (2007) who found that some LAB species such as $L$. casei and $L$. paracasei and Oenococcus oeni have the genetic capability of BA production (Moreno-Arribas and Polo, 2003). The primer pair AGD1f/AGDIR was used to discover agmatine Dihydrolase (Deiminase) gene. Figure $4 \mathrm{~B}$ presented the positive results revealed from PCR. The same strains that gave positive results for the presence of Ornithine decarboxylase gene, have also given positive results for the existence of agmatine dihyrolase (Deiminase) gene (Figure 4 lanes 2 to 9). Such findings accord with the results reported by Landete et al. (2007) who discovered the genes for BA production in $L b$. delbrueckii subsp. bulgaricus. On the other hand, many other lactobacilli can produce BA, including tyramine, e.g., some strains of $L b$. brevis or $L b$. paracasei (Landete et al., 2008). Some studies have shown the existence of a strain-dependent ability to form BA. For example, $O$. oeni strains were described as being histamine- or putrescine-formers (Coton et al., 1998; Marcobal et al., 2006). A $L b$. hilgardii strain, IOEB 0006, was also described as being a histamine-former; in this case the amine producing pathway was harbored by an unstable plasmid (Lucas et al., 2005). Concerning the ability of Lb. brevis to form tyramine, Lucas et al. (2003) showed, that this trait was encoded at the chromosomal level for the strain IOEB 9809. Additionally, Lucas et al. (2007) indicated that the presence of the tyrdc gene was a strain-dependent trait in Lb. brevis strains isolated from wines, which is confirmed in this study.

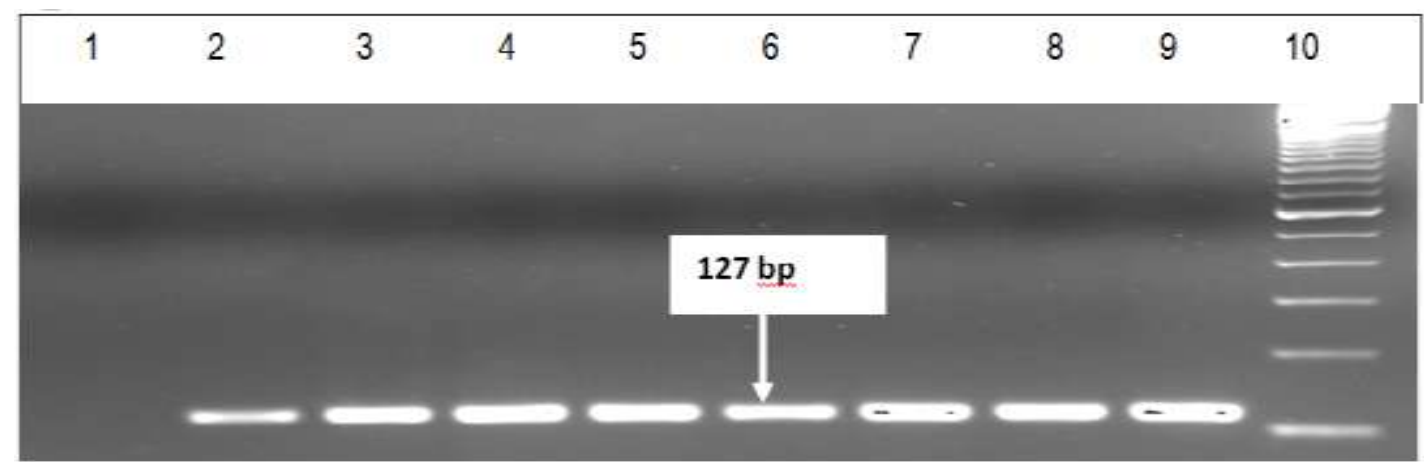

Figure 4 A. Detection of Ornithine decarboxylase gene in some strains. PCR products obtained with the primer AGD1f/AGDIR., lanes 1 and PCR control, lanes 2 and 3 PCR products of DNA from Lactobacillus Paracasei TISTR 453, lanes 4 and 5 PCR products of DNA from for Lactobacillus Casei DSMZ 20011, lanes 6 and 7 PCR products of DNA from Lactobacillus brevis, lanes 8 and 9 PCR products of DNA from $S$. thermophilus, lane 10 DNA ladder $100 \mathrm{bp}$.

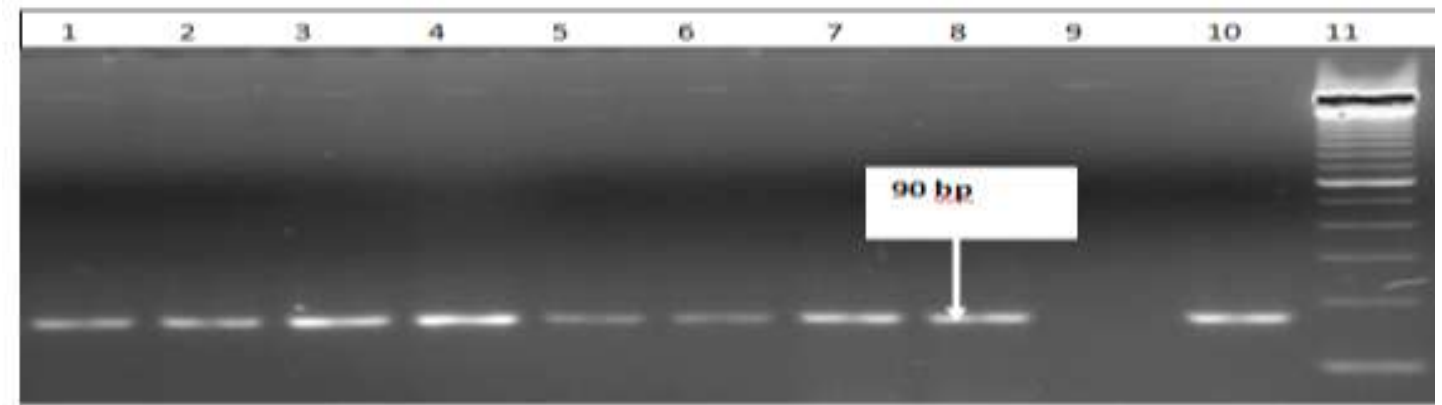

Figure 4 B. Detection of agmatine Dihydrolase (Deiminase) gene in some strains. PCR products obtained with the primer AGD1f/AGDIR. lane 1: PCR products by DNA from Lactobacillus paracasei TISTR 453, lanes 2: PCR products by DNA from Lactobacillus casei DSMZ 20011, lane: 3 PCR products by DNA from Lactobacillus brevis, lanes 4: PCR products by DNA from S. thermophilus, lane 5: PCR products by DNA from Lactobacillus brevis p102, lane 6: PCR products by DNA from Lactobacillus buchneri, lane 7: PCR products by DNA from Lactobacillus sanfrasiscensis DSM20451, lane 8: PCR products by DNA from Lactobacillus pentosus p160, lane 9: PCR products by water, lane 10 PCR control positive, lane 11: DNA ladder $50 \mathrm{bp}$. 


\subsubsection{Detection of putrescine gene}

The primer ODF/ODR was used to detect the ornithine decarboxylase gene and PCR products appeared at 500 bp (Granchi et al., 2006). Data in Figure $\mathbf{5}$ demonstrated the positive results produced by PCR technique. From data shown in figure 5 we could conclude that the putrescine gene is detected in L. paracasei TISTR 453, L. casei DSMZ 20011, L. brevis, Streptococcus. Thermophilus, Enterococcus faecium p187, Lb. delbrueckii subsp. bulgaricus. These findings agree with the results reported by Costantini et al. (2013) who found that the majority of the analyzed L. brevis harbour both AgDI and tdc genes and are tyramine and putrescine-producers. Conversely, among the other LAB tested, only one $L$. hilgardii and one Pediococcus pentosaceus produced putrescine. The AgDI gene was also discovered in two other LAB (Lactobacillus mali and pediococcus parvulus), but no putrescine production was observed. The hdc gene and histamine production were found in strains. Such results agree with a previous report by Costantini et al. (2006) wherein the presence of hdc gene in L. hilgardii 5211 strain isolated from wine was confirmed. The hdc gene was also present in L. casei 18 isolated from cider. These two strains were not putrescine-producers. Tyramine and histamine are the most represented BA in wine and cider. Significantly, tyramine has toxicological properties and is presumed to play an active role in the development of migraine, hypertension, psychological depression, schizophrenia, and Parkinson disorder (Branchek and Blackburn, 2003). Histamine has been associated with headache, allergies, and hypotension (Maintz and Novak, 2007). In the present investigation, most tyramine production observed is ascribable to $L$. brevis. Furthermore, results indicate that two strains belonging to different species of L. hilgardii 5211, isolated from wine, and L. casei 18, isolated from cider, also biosynthesize histamine are in agreement with their genetic pattern. Histamine production by L. casei has been previously demonstrated (Garai et al., 2007).

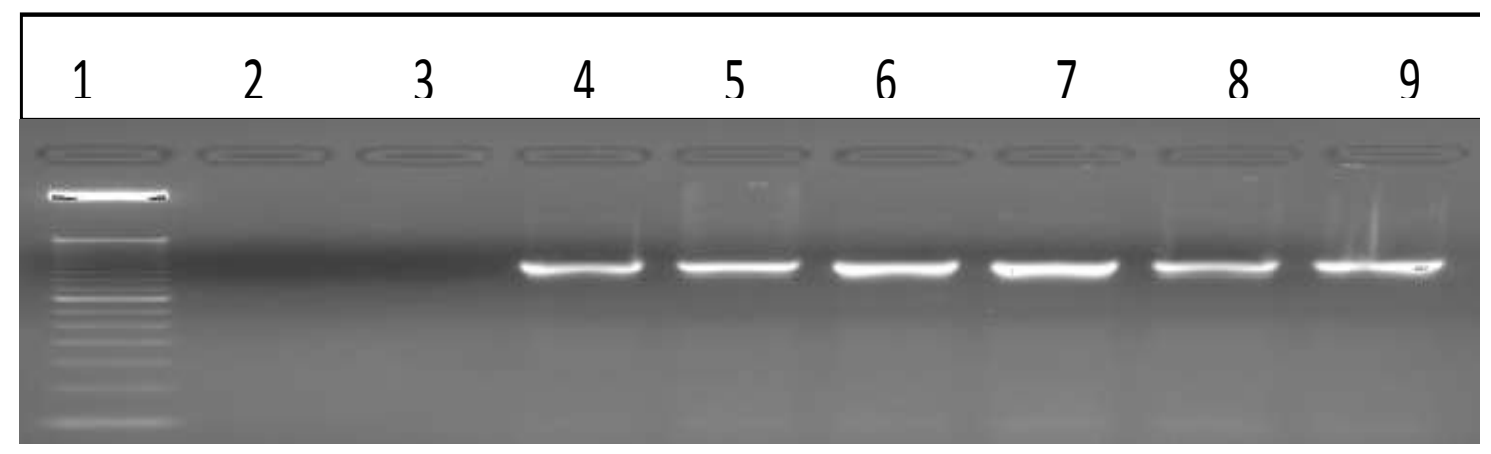

Figure 5: Detection of putrescine gene in some strains. PCR products obtained with the primer ODF/ODR. lanes 1 DNA ladder $50 \mathrm{bp}$, lanes: 2 and 3 PCR control without DNA, lane 4: PCR products by DNA from Lactobacillus paracasei TISTR 453, lane 5 PCR products by DNA from for Lactobacillus casei DSMZ 20011, lane 6: PCR products by DNA Enterococcus faecium p187, lane 7: PCR products by DNA from Lactobacillus brevis, lane 8: PCR products by DNA from $S$. thermophilus, lane 9: PCR products by DNA from Lb. delbrueckii subsp bulgaricus

\subsection{Determination of BA by TLC}

Data in Table 4 and Figure 6 show the levels of $\mathrm{BA}$ and the positive samples for different BA in microorganisms under investigation as determined by TLC. Only six strains from the strains under investigation were given positive results for producing putrescine. The strains L.. Casei DSMZ 20011 exhibited the greatest capacity for putrescine production (17.38 ppm), followed by L. Paracasei TISTR 453 (14.65 ppm) L. brevis13.59, Enterococcus faecium pl87 10.53, S. thermophilus (3.53) and the strain L.. delbrueckii subsp bulgaricus. demonstrated the lowest ability for producing putrescine amine. In the same table the ability of microorganisms for producing histamine was presented. The Enterococcus faecium p187 strain was given the highest ability for histamine production then L. brevis (12.88 ppm), L. pentosus p160 (4.46ppm), L. casei DSMZ 20011 (4.24 ppm), the L. rhamnosus TISTR 541 (2.75) while the $S$. thermophilus showed the lowest ability for producing histamine. Data reported in this study clearly show that seven strains gave positive results for tyramines production and casei DSMZ 20011 displayed the highest potential for tyramine production and the level was (2.85) while the lowest ability for tyramine production was for L. brevis p102 strain and the level was ( 0.76). Only eight strains were able to produce agamantine and they varied in this. The strains $L$. paracasei TISTR 453 showed the highest ability for agamantine production $(174.50 \mathrm{ppm})$ while the $S$. thermophilus produced the lowest yield (1.35 ppm). Comparable conclusions were documented by Costantini et al., (2013), who found that the majority of the L. brevis, L. hilgardii and Pediococcus pentosaceus produced putrescine. 
Table 4. Concentration of biogenic amines produced by lactic acid and bifidiobacteria

\begin{tabular}{|c|c|c|c|c|}
\hline \multirow[b]{2}{*}{ Strains } & \multicolumn{4}{|c|}{ Concentration of biogenic amines mg/kg (ppm). } \\
\hline & Putrescine & Histamine & Tyramines & Agamantine \\
\hline Lactobacillus acidophilus ATCC 20552 & - & - & - & - \\
\hline Lactobacillus paracasei TISTR 453 & 14.65 & & & 174.50 \\
\hline Lactobacillus rhamnosus TISTR 541 & - & 2.75 & & - \\
\hline Lactobacillus salivarius TISTR 390 & - & & & - \\
\hline Lactobacillus acidophilus TISTR 450 & - & & & - \\
\hline Lactobacillus johnsonii ATCC 33200 & - & & & - \\
\hline Lactobacillus casei DSMZ 20011 & 17.28 & 4.24 & & 10.63 \\
\hline Lactobacillus acidophilus DSM 9126 & - & - & & \\
\hline Lactobacillus acidophilus DSM20079 & - & - & & \\
\hline Lactobacillus acidophilus DSM20242 & - & - & & \\
\hline Lactobacillus sanfrasiscensis DSM20451 & - & - & & 4.89 \\
\hline Lactobacillus plantrum & - & - & & - \\
\hline Bifidobacterium infantis DSMZ 20088 & - & - & & - \\
\hline Bifidobacterium angulatum DSMZ 20098 & - & - & & - \\
\hline Lb. delbrueckii subsp bulgaricus & 1.96 & - & & - \\
\hline Lactobacillus acidophilus $P 2$ & - & - & & - \\
\hline Lactobacillus acidophilus P4 & - & - & & - \\
\hline Lactobacillus acidophilus P5 & - & - & & - \\
\hline Lactobacillus acidophilus $P 6$ & - & - & & - \\
\hline Lactobacillus acidophilus P7 & - & - & & - \\
\hline Lactobacillus acidophilus $P 8$ & - & - & & - \\
\hline Lactobacillus acidophilus $P 9$ & - & - & & - \\
\hline Lactobacillus acidophilus P112 & - & - & & - \\
\hline Lactobacillus acidophilus P106 & - & - & & - \\
\hline Lactobacillus plantarum $p 1$ & - & - & & - \\
\hline Lactobacillus brevis p102 & - & - & & 3.49 \\
\hline Lactobacillus pentosus p 160 & - & 4.46 & & 6.34 \\
\hline Enterococcus faecium pl87 & 10.53 & 31.77 & & - \\
\hline bifidobacterium longuium & - & & & - \\
\hline L. brevis & 13.59 & 12.88 & & 42.40 \\
\hline L. buchneri & - & - & & 11.76 \\
\hline S. thermophilus & 3.53 & 1.74 & & 1.35 \\
\hline
\end{tabular}

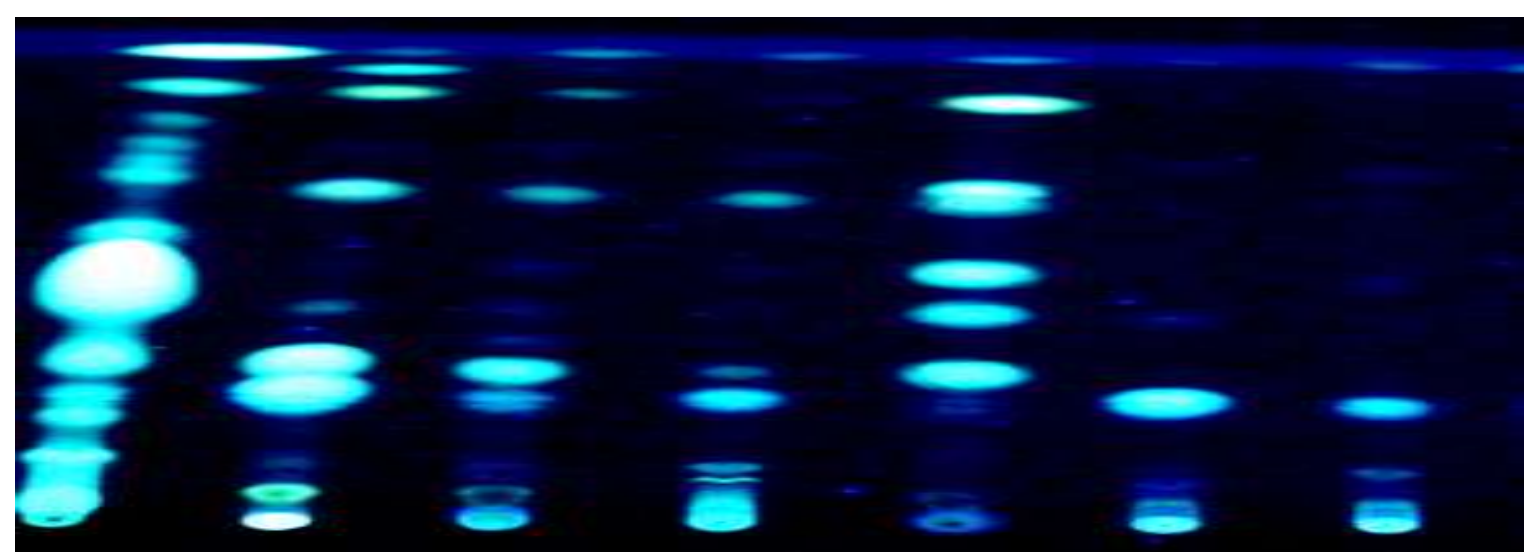

Figure 6: Examples of TLC plate for determination of different biogenic amines and the positive samples in some microorganisms under investigation.

In addition, Al Bulushi et al. (2009) found that most of the analyzed L. brevis strains were also able to produce tyramine, putrescine should be regarded not only as a molecule altering the wine organoleptic properties but also as a factor enhancing the risks of health effects exerted by tyramine on humans 
(headache and hypertension). The results obtained are in agreement with the statement that the production of BA in bacteria seems to be straindependent rather than related to bacterial species or even genera. This research also revealed that with the elevated amount of the precursor (tyrosine), the production of the corresponding BA (tyramine in this case) is increased in decarboxylation broth, which is in accordance with other studies (Fernández et al., 2007).

\section{Conclusions}

In conclusion, this work indicated that the ability to form BA are not a species-dependent trait in LAB. For the first time, the molecular basis for strains to strain variation in BA-formation in this species is provided. Most important, the obtained results will allow for studying the BA formation trait in other $\mathrm{LAB}$ encountered in various fermented food products. Based on these findings, it is recommended to carefully select and screen the strains for amino acid decarboxylase activity before selecting $\mathrm{LAB}$ as appropriate starter or probiotic strains in food and dairy production because of the potentional of horizontal transfer of gene(s) from microorganisms to others. This procedure would benefit from using specific and highly sensitive methods. i.e., utilizing molecular methods such as PCR and TLC methos.

\section{Acknowledgement}

The author is greatly indebted to Dr. Yousef Sultan, National Research center helping assistance during the determination of biogenic amines and Prof. Dr. Farid H. Badr in Faculty of agriculture and veterinary medicine, Qassim University, Kingdom of Saudi Arabia for his supporting me to achieve this work.

\section{References}

Al Bulushi, I., Susan, P., Hilton, C.D., Gary, A.D. (2009). Biogenic amines in fish: roles in intoxication, spoilage, and nitrosamine formation-a review. Critical Reviews in Food Science and Nutrition 49, 369-377.

Arena, M.E., Fiocco, D., Manca de Nadra, M.C., Pardo, I., Spano, G. (2007). Characterization of a Lactobacillus plantarum strain able to produce tyramine and partial cloning of a putative tyrosine decarboxylase gene. Curr. Microbiol. 55, 205210.

Arena, M.E., Manca de Nadra, M.C. ( 2001). Biogenic amines production by Lactobacillus. J. Appl. Microbiol. 90, 158-162.

Aymerich, T., Martin, B., Garriga, M., Vidal-Carou, C., Bover-Cid, S., Hugas, M. (2006). Safety properties and molecular strain typing of lactic acid bacteria from slightly fermented sausages. J. Appl. Microbiol. 100, 40-49.
Beresford, T., Williams, A. (2004). The microbiology of cheese ripening. In: Fox, P.F., McSweeney, P.L.H., Cogan, T.M., Guinee, T.P. (Eds.), Cheese Chemistry, Physics and Microbiology. Elsevier, Amsterdam, pp. 287317.

Bover-Cid, S., Hugas, M., Izquierdo-Pulido, M., Vidal-Carou, M.C. (2001). Amino acid decarboxylase activity of bacteria isolated from fermented pork sausages. Int. J. Food Microbiol. 66, 185-189.

Branchek, T.A., Blackburn, T.P. (2003). Trace amine receptors as targets for novel therapeutics: legend, myth and fact. Current Opinion in Pharmacology 3, 90-97.

Burdychova, R., Komprda, T. (2007). Biogenic amine-forming microbial communities in cheese. FEMS Microbiol. Lett. 276, 149-155.

Calles-Enriquez, M., Eriksen, B. H., Andersen, P. S., Rattray, F. P., Johansen, A. H., Fernandez, M., et al. (2010). Sequencing and transcriptional analysis of the Streptococcus thermophilus histamine biosynthesis gene cluster: Factors that affect differential hdcA expression. Applied and Environmental Microbiology, 76, 6231-5238.

Costantini, A., Cersosimo, M., Del Prete, V., GarciaMoruno, E. (2006). Production of biogenic amines by lactic acid bacteria: screening by PCR, thin-layer chromatography and high-performance liquid chromatography of strains isolated from wine and must. Journal of Food Protection 69, 391-396.

Costantini, A., Pietroniro, R., Doria, F., Pessione, E., Garcia-Moruno, E. (2013). Putrescine production from different amino acid precursors by lactic acid bacteria from wine and cider. International Journal of Food Microbiology 165, 11-17.

Coton, E., Coton, M. (2005). Multiplex PCR for colony direct detection of Gram-positive histamine- and tyramine-producing bacteria. J. Microbiol. Methods 63, 296-304.

Coton, E., Coton, M. (2009). Evidence of horizontal transfer as origin of strain to strain variation of the tyramine production trait in Lactobacillus brevis. Food Microbiol. 26, 52-57.

Coton, E., Rollan, G., Bertrand, A., Lonvaud-Funel, A. (1998). Histamine-producing lactic acid bacteria in wines: Early detection, frequency, and distribution. Am. J. Enol. Vitic. 49, 199- 204.

Coton, M., Berthier, F., Coton, E. (2008). Rapid identification of the three major species of dairy obligate heterofermenters L. brevis, L. fermentum and $L$. parabuchneri by species-specific duplex PCR. FEMS Microbial let. 7, 284, (2): 150-157.

Coton, M., Coton, E., Lucas, P., Lonvaud-Funel, A. (2004). Identification of the geneencoding a putative tyrosine decarboxylase of Carnobacterium divergens. Development of molecular tools for the detection of tyramineproducing bacteria. Food Microbiol. 21, 125-130. 
Coton. M., Romano, A., Spano, G., Ziegler, K., Vetrana, C., Desmarais, C., Lonvaud-Funel, A., Lucas., P., Coton, E. (2010). Occurrence of biogenic amine-forming lactic acid bacteria in wine and cider. Food Microbiology 27, 1078 1085.

De las Rivas, B., Rodriguez, H., Carrascosa, A. V., Munoz, R. (2008). Molecular cloning and functional characterization of a histidine decarboxylase from Staphylococcus capitis. Journal of Applied Microbiology, 104, 194-203.

De, S., Kaur, G., Roy, A., Dogra, G., Kaushik, R., Yadav, P., Singh, R., Datta, T.K., and Goswami, S. (2010). A simple method for the efficient isolatin of genomic DNA from Lactobacilli isolated from traditional Indian fermented milk (dahi). Indian J Microbiol. 50(4): 412-418.

Del Campo, G., Lavado, I., Duenas, M.T., Irastorza, A. (2000). Histamine production by some lactic acid bacteria isolated from ciders. Food Sci. Technol. Int. 6, 117-121.

Elsanhoty, R.M., Mahrous, H.A., Gohnamy, A.G. (2009). Chemical, microbiological counts and evaluation of biogenic amines during the ripening of Egyptian soft Damiati cheese made from raw and pasteurized buffaloes milk. International Journal of Dairy Science. 1-11.

Fernández M., Linares DM, Rodríguez A., Alvarez, M.A. (2007a). Factors affecting tyramine production in Enterococcus durans IPLA655. Appl. Microbiol. Biotechnol. 73:1400-1406.

Fernández, M., Linares, D.M., Del Rio, B., Ladero, V., Alvarez, M.A. (2007b). HPLC quantification of biogenic amines in cheeses: correlation with PCR-detection of tyramine-producing microorganisms. J. Dairy Res. 74, 276-282.

Garai, G., Duenas, M.T., Irastorza, A., MartinAlvarez, P.J., Moreno-Arribas, M.V. (2006). Biogenic amines in natural ciders. J. Food Prot. 69, 3006-3012.

Garai, G., Duenas, M.T., Irastorza, A., MorenoArribas, M.V. (2007). Biogenic amine production by lactic acid bacteria isolated from cider. Lett. Appl. Microbiol. 45,473-478.

Gezginc, Y., Akyol, I., Kuley, E., Zogul, F. (2013). Biogenic amines formation in Streptococcus thermophilus isolated from home-made natural yogurt. Food Chemistry 138, 655-662.

Gonza'lez de Llano, D., Cuesta, P., Rodriguez, A. (1998). Biogenic amine production by wild lactococcal and leuconostoc strains. Lett. Appl. Microbiol. 26, 270-274.

Gonzaga, V.E., Lescano, A.G., Huamàn, A.A., Salmann-Mulanovich, G., Blazes, D.L. (2009). Histamine levels in fish from markets in Lima, PerÚ Journal of Food Protection 72, 1112-1115.

Granchi, L.G., Talini, D., Rigacci, S., Guerrini, S., Berti, A., Vincenzini, M. (2006). Detection of putrescine-producer Oenococcus oeni strains by
PCR. 8th Symposium On Lactic Acid Bacteria, The Netherlands.

Granchi, L., Paperi, R., Rosellini, D., Vincenzini, M. (1998). Strain variation of arginine catabolism among malolactic Oenococcus oeni strains of wine origin. Ital. J. Food Sci. 4, 351- 357.

Holt, J.G., Krieg, N.R.,Sneath, P.H.A.,Staley, J.T., Williams, S.T. (1994). Bergeys' Manual Determinative of Bacteriology (9th ed.). Baltimore: Williams and Wilkins.

Izquierdo Canas, P.M., Gomez Alonso, S., Ruiz Perez, P., Sesena Prieto, S., Garcia Romero, E., Palop Herreros, M.L. (2009). Biogenic amine production by Oenococcus oeni isolates from malolactic fermentation of Tempranillo wine. J. Food Prot. 72, 907-910.

Konings, W.N. (2002). The cell membrane and the struggle for life of lactic acid bacteria. Antonie Van Leeuwenhoek 82, 3-27.

La Gioia, F., Rizzotti, L., Rossi, F., Gardini, F., Tabanelli, G., \& Torriani, S. (2011). Identification of a tyrosine decarboxylase gene (tdcA) in Streptococcus thermophilus 1TT45 and analysis of its expression and tyramine production in milk. Applied and Environmental Microbiology, 77, 1140-1144.

Ladero, V., Martínez, N., Martín, M.C., Fernández, M., Alvarez, M.A. (2010). qPCR for quantitative detection of tyramine-producing bacteria in dairy products. Food Res. Int. 43, 289-295.

Landete JM., De las Rivas, B., Marcobal A, Muñoz R. (2008). Crit Rev Food Sci Nutr 48:697-714.

Landete, J.M., De Las Rivas, B., Marcobal, A., Muñoz, R. (2007). Molecular methods for the detection of biogenic amine-producing bacteria on foods. Int. J. Food Microbiol. 117, 258-269.

Lonvaud-Funel, A., and Joyeux, A. (1994). Histamine production by wine lactic acid bacteria: Isolation of a histamine-producing strain of Leuconostoc oenos. J. Appl. Bacteriol. 77, 401-407.

Lorencová, E., Buňková L., Matoulková, D., Dráb, V., Pleva, P., Kubán̆, V., Buňka, F. (2012). Production of biogenic amines by lactic acid bacteria and bifidobacteria isolated from dairy products and beer. International Journal of Food Science and Technology. 47, 10, 2086-2091.

Lucas, P., Claisse, O., Lonvaud-Funel, A. (2008). High frequency of histamine producing bacteria in enological environment and instability of the phenotype. Appl. Environ. Microbiol. 74, 811817.

Lucas, P., Landete, J., Coton, M., Coton, E., Lonvaud-Funel, A. (2003). The tyrosine decarboxylase operon of Lactobacillus brevis IOEB 9809: characterization and conservation in tyramine-producing bacteria. FEMS Microbiol. Lett. 229, 65-71.

Lucas, P.M., Blancato, V.S., Claisse, O., Magni, C., Lolkema, J.S., Lonvaud-Funel, A. (2007). 
Agmatine deiminase pathway genes in Lactobacillus brevis are linked to the tyrosine decarboxylation operon in a putative acid resistance locus. Microbiology 153, 2221-2230.

Lucas, P.M., Wolken, W.A., Claisse, O., Lolkema, J.S., Lonvaud-Funel, A. (2005). Histamineproducing pathway encoded on an unstable plasmid in L. hilgardii 0006. Appl. Environ. Microbiol. 71, 1417-1424.

Mahrous, H. (2006). Functionalities of Lactic Acid Bacteria isolated from Egyptian environment, PhD Thesis, Genetic Engineering \& Biotechnology Research Institute (GEBRI) Minufiya University.

Maintz, L., Novak, N., 2007. Histamine and histamine intolerance. American Journal of clinical nutrition, 8, 5, 1185-1196

Martin-Alvarez P., Marcobal A., Polo C., MorenoArribas, M.V. (2006). Influence of technological practices on biogenic amine contents in red wines. European Food Research and Technology , 222, 420-424.

Maijala R.L, Eerola S.H. (1993). Contaminant lactic acid bacteria of dry sausages produce histamine and tyramine. Meat sci., 35: 387-395.

Mietz J.L., Karmas, E. (1978). Polyamine and histamine content of rock fish, salamon, lobster and shrimp as an indicator of decomposition. J. AOAC, 16(1): 139-145.

Marcobal, A., de las Rivas, B., Muñoz, R. (2006). Methods for the detection of bacteria producing biogenic amines on foods: A survey. Journal of Consumer Protection and Food Safety. 1, 187196.

Marcobal, A., Las Rivas, B., Moreno-Arribas, M.V., Muñoz, R. (2004). Identification of the ornithine decarboxylase gene in the putrescine-producer Oenococcus oeni BIFI-83. FEMS Microbiology Letters 239, 213-220.

Marcobal, A., de las Rivas, B., Moreno-Arribas, M.V., Muñoz, R. (2005). Multiplex PCR method for the simultaneous detection of histamine-, tyramine-, and putrescine-producing lactic acid bacteria in foods. Journal of Food Protection 68, 874-878.

Moreno-Arribas, M.V., Polo, M.C., Jorganes, F., Munoz, R. (2003). Screening of biogenic amine production by lactic acid bacteria isolated from grape must and wine. Int. J. Food Microbiol. 84, $117-123$.

Moreno-Arribas, M.V., Polo, M.C. (2008). Occurrence of lactic acid bacteria and biogenic amines in biologically aged wines. Food Microbiol. 25, 875-881.

Moreno-Arribas, M.V., Torlois, S., Joyeux, A., Bertrand, A., Lonvaud-Funel, A. (2000). Isolation, properties and behaviour of tyramine- producing lactic acid bacteria from wine. J. Appl. Microbiol. 88, 584-593.

Nannelli, F., Claisse, O., Gindreau, E., de Revel, G., Lonvaud-Funel, A., Lucas P.M. (2008). Determination of lactic acid bacteria producing biogenicamines in wine by quantitative PCR methods. Letters in Applied Microbiology, 47, 594-599

Rossi, F., Gardini, F., Rizzotti, L., La Gioia, F., Tabanelli, G., Torriani, S. (2011). Quantitative analysis of histidine decarboxylase gene (hdca) transcription and production by Streptococcus thermophilus PRI60 under conditions relevant to cheese making. Appl Environ Microbiol. 77(8): 2817-2822.

Ruiz-Capillas, C., Jimenez-Colmenero, F. (2004). Biogenic amines in meat and meat products. Crit. Rev. Food Sci. Nutr. 44, 489-499.

Sambrook, J., Fritsch, E. F., and Maniatis, T. (1989). Molecular cloning: A laboratory manual, 2nd ed. Cold Spring Laboratory, Cold Spring Harbor, NY.

Satomi, M., Furushita, M., Oikawa, H., YoshikawaTakahashi, M., Yano, Y. (2008). Analysis of a 30 kbp plasmid encoding histidine decarboxylase gene in tetragenococcus halophilus isolated from fish sauce. International Journal of Food Microbiology, 126, 202-209.

Shalaby, A.R. (1996). Significance of biogenic amines in food safety and human health. Food Res. Int. 29, 675-690.

Silla Santos, M.H. (1996). Biogenic amines: their importance in food. Int. J. Food Microbiol. 29, 213-231.

Straub, B.W., Kicherer, M., Schilcher, S.M., Hammes, W.P. (1995). The formation of biogenic amines by fermentation organisms. Z. Lebensm.Unters. Forsch. 201, 79-82.

Suzzi, G., Gardini, F. (2003). Biogenic amines in dry fermented sausages: a review. Int.J. Food Microbiol. 88, 41-54.

Ten Brink, B., Damink, C., Joosten, H.M.L.J., Huis In't Veld, J.H.J. (1990). Occurrence and formation of biologically active amines in foods. Int. J. Food Microbiol. 11, 73-84.

Trip, H., Mulder, N.L., Rattray, F.P., Lolkema, J.S. (2011). HdcB, a novel enzyme catalysing maturation of pyruvoyl-dependent histidine decarboxylase.79, 4, 861-871.

Verges, C.M.C., Zuniga, M., Morel-Deville, F., Perez-Martinez, G., Zagorec, M., Ehrlich, S.D., (1999). Relationships between arginine degradation, $\mathrm{pH}$ and survival in Lactobacillus sakei. FEMS Microbiol. Lett. 180, 297-304.

Wathersen, J.J., Scanlan, R.A., Bills, D.D., Libbey, L.M. (1975). Formation of heterocyclic Nnitrosamines from the reaction of nitrite and selected primary diamines and amino acids. J. Agric. Food Chem. 23, 898-902. 


\title{
تقييم بعض بكتريا حمض اللاكتيك والمعاونات الحيوية لقرتها علي إنتاج الأمينات الحيوية
}

\author{
رأفت محمد السنهوتي \\ قسم البيتكنولوجيا الصناعية، فرع بيوتكنولوجيا الأغذية والألبان، معهد الهندة الوراثية والتكنولوجيا الحيوية، جامعة مدينة السادات، مصر •
}

تعتبر الأمينات الحيوية من المواد السامة الني لها نأثثر سيء علي صحة الإنسان لذلك ينبغي أن يؤخذ في الاعتبار القدرة المحتملة للميكروبات

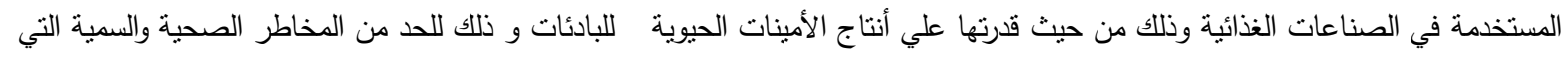
تسبيها هذه المركبات .وبالتالي، يهدف هذا العمل إلى دراسة احتمالية إنتاج الأمينات الحيوية من بكتريا حصض اللاكتيك (LAB) والمعاونات الحيوية المستخدمة في المنتجات الغذائية وغيرها المعزولة من الأطفال الرضع. اشتمل برونوكول التحليل استخدام تقنيات تفاعل البلمرة المتسلسل وكروماتوغرافيا الطبقة الرقيقة (TLC) لتحديد قدرتها علي تكوين الأمينات الحيوية .أنشارت النتائج إلى أن هناك بعض الميكروبات من الميكروبات الني اختيرت لها القدرة على إنتاج الأمينات الحيوية. حيث أعطت ستة سلالات-من أصل أثنثين وثثلاثين سلالة-نتائج إيجابية لإنتاج

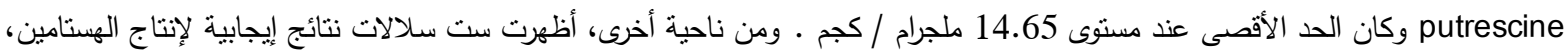
وكان الحد الأقصى لإنتاجها 31.77 ملجرام / كجرام. كما أوضحت وجود الجين المسئول عن المقدرة للإنتاج كما أظهرت معطيات الدراسة نتائج

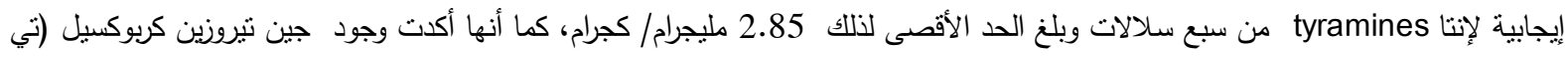

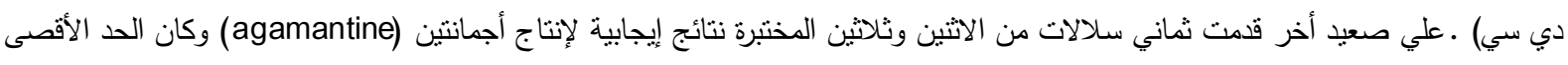
لقدرتها 174.50 مليجرام / كجم، كما أظهرت دلالات إيجابية علي وجود جين أجماتين. بناءا علي النتائج التي نم الحصول عليها فأننا نوصي بعمل فحص دقيق للتعرف علي قدرة الكائنات الحية الدقيقة المستخدمة في إنتاج

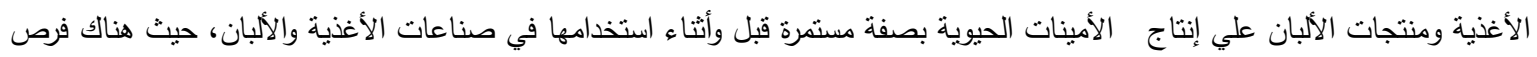
محتملة لحدوث انتقال أفقي للجينات المسئولة بين الميكروبات وبعضها مدا يودي إلي حدوث التيات اختلاف في الميكروبات ويكسبها القدرة علي تكوين مركبات غير مرغوبة صحيا في الأغذية. 